\title{
US elections may pose challenge for Bush agenda
}

\author{
by Dr Kern Alexander
}

$\mathrm{T}$ he US 2002 congressional elections reaffirmed Republican ascendancy in American politics by decisively placing the Republican Party in control of the US Congress. Not only did the Republicans extend their majority in the House of Representatives by 11 seats, they also regained control of the Senate, which they lost in 2000 when Vermont Senator James Jeffords left the Republican party to join forces with Senate Democrats. In light of the 2000 election debacle, the 2002 mid-term elections were crucial for President Bush to reaffirm key aspects of his legislative agenda that include tax cuts, increased defence spending, and homeland security. Indeed, Republican control of the Senate means that the Democrats will no longer possess the chairmanships of the Senate committees, which is where real power lies in drafting, adopting and implementing legislation.

The Republicans will thus be able to control the legislative agenda in both Houses of Congress and this will have important implications for the statutory and regulatory framework governing corporate governance reform, banking regulation, and the war on terror. Moreover, because of its advice and consent role in approving treaties and judicial appointees, Senate committee chairmen will decide the fate of proposed legislation and treaties, and oversee the implementation of recently enacted statutes.

\section{NEW COMMITTEE CHAIRMEN}

President Bush has thus far proved to be a consummate legislative dealmaker in working with the 107th Congress to get a number of important bills enacted into law. Of particular importance has been his ability to gain bipartisan support amongst Republicans and conservative Democrats to achieve tax cuts and wideranging laws to regulate the financial sector and to restrict the constitutional liberties of persons who are allegedly involved in terrorism or money laundering. Notwithstanding success in these areas, Bush's reelection prospects in 2004 will depend largely on how well he works with the new Republican chairmen of the
Senate Committees. In particular, three committee chairmen will exercise significant influence over key aspects of the Bush economic and foreign policy agenda.

The chairmen are Richard Shelby of Alabama of the Banking, Housing and Urban Affairs Committee, Orrin Hatch of Utah of Judiciary Committee, and Richard Lugar of the Foreign Affairs Committee. These committees have jurisdiction respectively over corporate governance and financial regulation, the judiciary and the war on terror, and treaties and international relations. Although the three chairmen are likely to provide crucial support for many Bush initiatives, each holds strong views that run counter to some areas of the Bush agenda that might pose future problems for the president.

Senator Shelby, for instance, has clashed frequently with financial institutions over customer privacy and has criticised key provisions of the Gramm-Leach-Blilely Act 1999 that allow the subsidiaries and divisions of financial holding companies to trade customer names and financial information with competitors without first obtaining customer permission. In today's Wall Street environment, his views may attract public support that might undermine existing efforts by the Bush administration to block any efforts to reform the law. Shelby has also announced that he wants to play an active role in implementing the newly-enacted Sarbanes-Oxley Act (named after former Banking Committee Chairman Paul Sarbanes, D-Maryland). He has a particular interest in accounting reform and giving the SEC more authority to regulate corporate governance standards and to ensure greater transparency and accountability in capital markets.

Moreover, Shelby has worked with consumer advocate and former Green Party presidential candidate Ralph Nader to support legislation that would give investors increased rights to sue companies that defraud their shareholders and the lawyers and accountants who aid and abet them. He also sided with Alan Greenspan in opposing Republican proposals supported by the US banking industry to increase the limit on federallyinsured deposits from the current $\$ 100,000$ per account. 


\section{RESTORING INVESTOR CONFIDENCE}

Shelby has also emphasised that the new Chairman of the Securities and Exchange Commission should not only have expertise and experience in financial markets, but also be politically independent of the White House. He views this as essential for restoring investor confidence after the US corporate governance scandals that have ravaged Wall Street and contributed to continuing uncertainty in financial markets. Shelby has also recognised that his pre-Arthur Andersen criticisms of former SEC Chairman Arthur Levitt's proposals to bar auditors from performing consultancy work for their public company clients were a mistake. He now considers the next stage of implementing the Sarbanes-Oxley Act through administrative rule writing by the SEC to be crucial and that his committee will be closely involved in overseeing this process. Although he has not yet expressed a position on the Act's extraterritorial application for nonUS companies with US listings, he will likely support SEC efforts to encourage foreign regulators to adopt some version of the US standards.

Richard Lugar will become the chairman of the Senate Foreign Relations Committee, which has jurisdiction over US treaty making and international affairs, especially legal affairs that deal with such important topics as the International Criminal Court. Lugar succeeds Jesse Helms as the committee's most senior Republican senator. Helms achieved notoriety as a unilateralist, a UN Critic, and the author of important legislation dealing with economic sanctions, such as the Helms-Burton Act that imposes extraterritorial sanctions on foreign companies or persons who invest in confiscated Cuban property.

Lugar has substantial experience in foreign policy, having served as chairman of the Foreign Relations Committee in the 1980s during the Reagan administration. He played a crucial role in steering Reagan foreign policy away from its unilateralist position of supporting the South African apartheid regime to a more multilateral approach that involved using economic and financial sanctions to bring about political reform. Lugar also was instrumental in negotiating Ferdinand Marcos's abdication from power in the Philippines and bringing about a peaceful democratic transition in that country.

In recent years, he has supported the Helms-Burton Act and has criticised the international criminal court treaty as not providing sufficient immunities for US military personnel. However, he advocates a more engaged policy with Cuba that involves a loosening of the US 42-year embargo and has actively engaged foreign diplomats in trying to find a compromise treaty that can meet US objections. Lugar's foreign policy experience is without parallel among Bush's senior advisers and cabinet officers, and many hope that he will play a role in steering US foreign policy away from its unilateralist posture to a more moderate approach will be welcomed by US allies and the international community. He will be far less suspicious than his Republican predecessor, Jesse Helms, in using the United Nations and other international organisations to accomplish US objectives.

Orrin Hatch becomes chairman of the Senate Judiciary Committee. Hatch, an avowed social and economic conservative, who however at times has demonstrated a maverick streak, will control the approval of president Bush's judicial appointees and federal prosecutors. His committee also is overseeing the implementation of the criminal provisions of the US Patriot Act 2001. Hatch has expressed some reservations concerning the draconian provisions of the Act that allow US authorities to detain US and non-US citizens indefinitely without seeing a lawyer if they are suspected of being combatants in the war against terrorism. Overall, however, he remains a key supporter of the president and will be less likely than the other two chairmen to stray from administration policy.

Most recently, Hatch has supported the controversial nomination of Professor Michael McConnell of the University of Utah Law School to the Tenth Circuit Court of Appeal. Professor McConnell has written critical commentaries arguing against the traditional view of the US Constitution's First Amendment providing for the separation of church and state and the free exercise of religion. Hatch supports McConnell's view that state neutrality regarding religion does not preclude the state from providing financial support for religious activities. This will fit nicely with President Bush's views on church and state that also permit state support of religious activities.

The success of the Bush agenda, and his re-election, will depend largely on his success in working with key congressional committee chairman, such as senators Shelby, Lugar, and Hatch, whose committees have jurisdiction over key areas of Bush economic, criminal justice and foreign policy. It is too early to tell what position these senators will take on important issues that will impact legislation that will affect the international community in many ways. Any efforts to influence US policy in these issue areas should take account of the important these senators play.

\section{Dr Kern Alexander}

Butterworths Senior Research Fellow, International Financial Regulation, and Postgraduate Tutor in Law, Institute of Advanced Legal Studies; former Legislative Aide, United States Senate Commerce Committee; Attorney, State of Florida; Solicitor of the Supreme Court of England and Wales. 